\title{
Analysis on the Level of Intra-industry Trade for ASEAN's Economy
}

\author{
Thanet Wattanakul \\ Khon Kaen University, Nong Khai, Thailand
}

\begin{abstract}
This paper aims to examine and analyse the level of intra-industry trade on economy of ASEAN. These data obtained from the accurate and reliable source of ASEAN Trade Statistics databases. The importance of intra-industry and measurement is also described. Moreover, the linkage of intra-industry trade and investment liberalization under the ASEAN Economic Community (AEC) is also explained. The effective enhancement schemed to increase the competitiveness of specific industries had been proposed to enhance ASEAN to be efficient production hub and network of region that lead to the ultimate goal of single market. The further studies can be applied to construct and estimate the econometric model and forecasting technique to confirm the empirical results.
\end{abstract}

Keywords: intra-industry trade, ASEAN, AEC, trade and investment liberalisation

\section{Introduction}

Economic and financial crisis attacked the Asian region starting from Thailand in 1997. Almost all countries in this region had been domino affected by the crisis. The economic growth and structural changes have been emerged particularly for the past two decades. This growth can be regarded as miracle growth because of the spectacular growth of performance characteristics. Many perspectives can explain this experience as follows. These aspects can be divided into two factors as primary and secondary factors. The miracle growth also associated with the economic policy implementation as well as the changing of trade policy and the attraction of massive foreign direct investment especially in the industrialised export production (Dowling \& Valenzuela, 2004). As a consequence, all Southeast Asian economies grew very rapidly over expectation especially in the 1990 s.

Nevertheless, many countries in this region had been domino affected by the crisis. The enhancement of intra-industry trade for important industries had been proposed and implemented by trade and investment liberalisation policy to accelerate ASEAN's economy growth. Both tariff and non-tariff barriers (NTBs) have to be eliminated under the agreement. The efficient regional production hub and network need be concerned by all members. Moreover, the enhancement of intra-industry trade under the specialization perspective in the region

\footnotetext{
* Acknowledgement: This research had been undertaken by budget granted from the Research Administration Division, Research and Technology Transfer Department, Khon Kaen University.

Thanet Wattanakul, assistant professor, Department of Economics, Faculty of Integrated Social Sciences, Khon Kaen University, Nong Khai Campus, Indo-China Country International Trade and Economy Research Sector, Nong Khai, Thailand.

Correspondence concerning this article should be addressed to Thanet Wattanakul, Department of Economics, Faculty of Integrated Social Sciences, Khon Kaen University, Nong Khai Campus, Indo-China Country International Trade and Economy Research Sector, Nong Khai, Thailand.
} 
has been proposed and debated among economists. Therefore, the issue of analysis level and impact of intra-industry trade on ASEAN's economy are very interesting to study.

\section{Review Literature}

This section reviews the related literature to explore the research gap and determine objectives of study.

Elliott and Ikemoto (2004) used a modified gravity equation to examine ASEAN's intra- and extraregional bias in bilateral trade flows and how these relationships have changed overtime. The investigated period covered before and after the signing of ASEAN Free Trade Agreement (AFTA) as well as the crucial years prior to and following the Asian crisis. By given the "openness" of ASEAN countries, the consideration is not only intra-ASEAN trade but also the effect of AFTA on non-members. It is found that trade flows were not significantly affected in the years immediately following the signing of the AFTA agreement. Additionally, the policy implementation of ASEAN countries to focus on an outward oriented economic activity has not been significantly affected but rather stimulated by the AFTA process and/or the Asian economic crisis. One important effect of the Asian economic crisis was to generate a stronger desire to source imports from within the region and in particular for intra-industry trade pattern.

It can be stated that most of the related literature has undertaken by concentrating on the structure or pattern and impact of intra-ASEAN regional trade. Therefore, the level and impact of intra-industry trade on ASEAN's economy are very interesting to consider the support that whether ultimate target of single market via enhancing intra-industry trade is mutual beneficial to members.

\section{Important and Measurement of Intra-industry Trade}

The ultimate target of ASEAN regional integration is to be single market. One important condition is trade and investment liberalisation to assure the expansion of intra-industry trade. All members have to address which industries have high production specialisation and competitiveness. These industries need to be categorised and prioritised as target industries to develop via the mutual agreements (Wattanakul, 2010). Nevertheless, these mutual agreements should be adjusted in term of appropriateness and flexibility for all new members consisting of Cambodia, Laos, Myanmar, and Vietnam (CLMV).

The explanation of intra-industry trade is also presented in this section prior to propose conceptual framework and econometric model and estimation methods. The intra-industry trade level (IIT) can be measured by using the IIT index as follows (Appleyard \& Field, 1997).

Giving the intra-industry trade happens within a selected commodity, the intra-industry trade can be measured by using the IIT. The changes of this index measurement are very useful because it shows the improvement of a country from time to time and allows the comparison of different countries.

If the commodity category is represented by $i$ and exports and imports in this category are represented by $\mathrm{X}_{i}$ and $\mathrm{M}_{i}$ respectively. The total exports and imports of same category are represented by $\mathrm{X}$ and $\mathrm{M}$. Therefore, the IIT can be shown in formula to calculate the intra-industry trade degree as follows (Appleyard \& Field, 1997, pp. 199-200).

$$
\mathrm{IIT}=1-\frac{\sum\left(X_{i} / X\right)-\left(M_{i} / M\right)}{\sum\left(X_{i} / X\right)+\left(M_{i} / M\right)}
$$

From the above, the $\left(\mathrm{X}_{i} / \mathrm{X}\right)$ and $\left(\mathrm{M}_{i} / \mathrm{M}\right)$ are regarded as the country's total export and import percentage in the selected category $i$ and $\left(\mathrm{X}_{i} / \mathrm{X}\right)-\left(\mathrm{M}_{i} / \mathrm{M}\right)$ shows the difference between the share of exports and imports in 
the category in absolute value. The $\sum\left(\mathrm{X}_{i} / \mathrm{X}\right)+\left(\mathrm{M}_{i} / \mathrm{M}\right)$ presents sum of exports and imports share in the category. The $\sum$ means the overall summing of the commodity categories.

The index value lies between 0 and 1 . The different value affirms the moderate level if the value is approximately 0.5 . The value of 1 means total intra-industry trade that exports equal to imports in each category.

Comparative advantage based on factor endowments gradually assists to forecasting intra-industry. Intra-industry trade is more related to the factor endowments of the investigated country. Besides, one essential deficiency assumption of the Heckscher-Ohlin's theory is the reliable explanation of intra-industry trade. The pattern of trade under Heckscher-Ohlin's theory is only inter-industry trade between the different factor intensity commodities of labour and capital intensive commodities. Many reasons can be explained to support this argument as follows (Appleyard \& Field, 1997):

(1) Product differentiation

(2) Transportation costs

(3) Geographical location

(4) Dynamic economies of scale

(5) Degree of product aggregation

(6) Income distribution differentiation

The measurement of intra-industry trade had been examined to test various specific hypotheses as follows (Appleyard \& Field, 1997).

(1) Higher level of income per capita is associated with a higher amount of intra-industry trade.

(2) There is positive relationship between country's total income because more economies of scale lead to larger national income.

The above hypotheses are generally confirmed. The level of intra-industry trade is positively correlated with many factors such as income per capita, national income, openness, and the common border with trading partners. In contrast, transportation cost is measured by distance from trading partners, which is negatively correlated with intra-industry level.

Additionally, it can be stated that the intra-industry trade is an economic situation which reflects the production and trade pattern complexity in reality that cannot be described by other international trade theories. The intra-industry trade is not only beneficial to trading partners in term of various product differentiations, but also more variety of goods to consumers.

\section{Conceptual Framework}

This section proposes and explains the conceptual framework to address the objectives of the study. The conceptual framework can be described as follows.

It can be described from the above conceptual framework that the essential related aspects need to be discussed prior to examine and analyse the level and impact of selected intra-industry trade on the economy of ASEAN. These aspects consist of regional economic integration that one important condition is trade and investment liberalisation that leads to the expansion of intra-regional and intra-industry trade. In addition, the policy implications and recommendations are also proposed to support and be transmission channels to link the intra-industry and ASEAN's economy development and growth. 


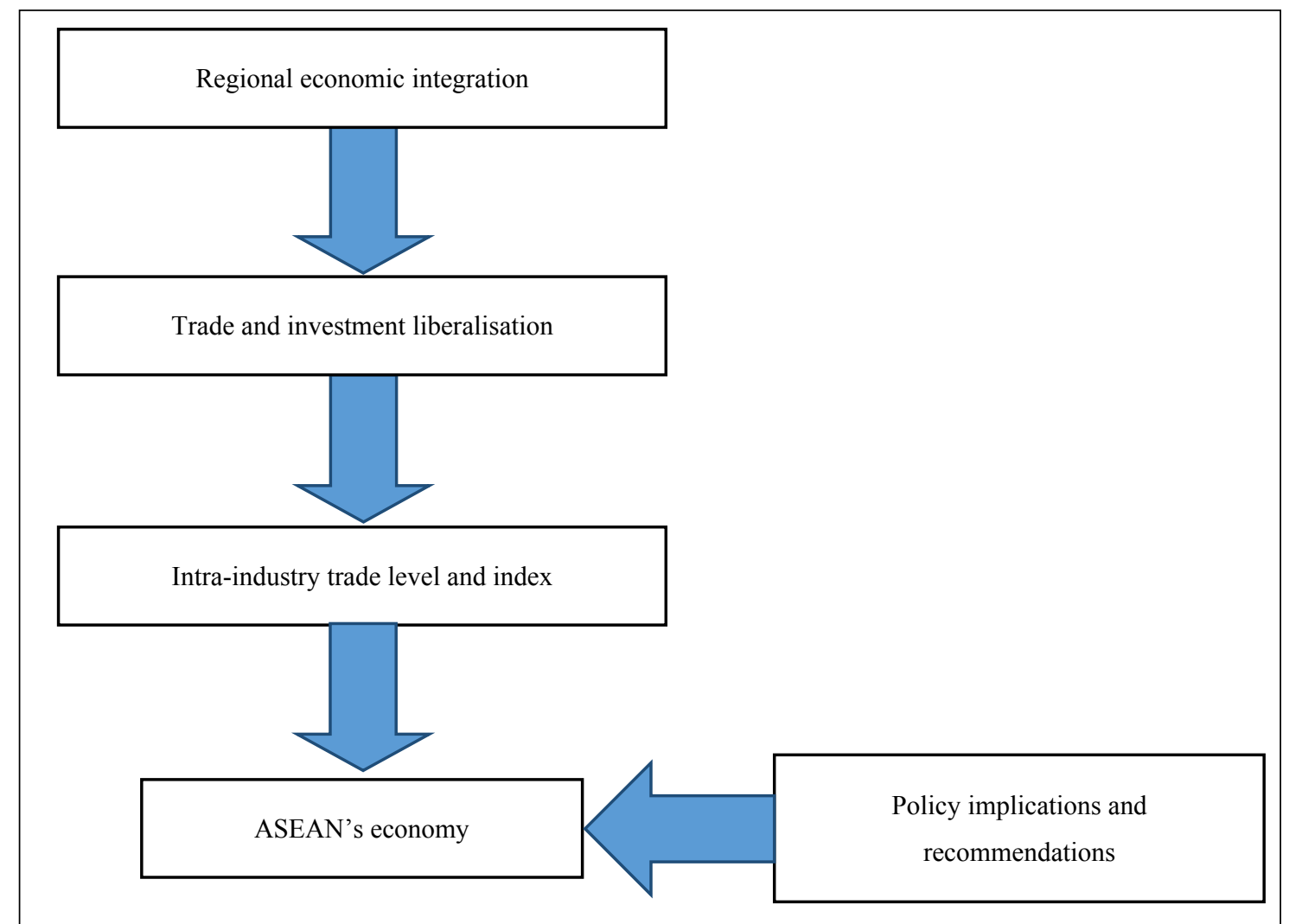

Figure 1. Conceptual framework. Source: From the theoretical framework and review literature.

\section{Trend of Intra-industry Trade of ASEAN}

This section examines trend of intra-industry of ASEAN. This intra-industry trade is selected under the context of ASEAN Investment Agreement (AIA). The specific industries of each member have to be explored to propose according to this agreement. As a consequence, each member has different potential and competitiveness in different industries. The acceleration of intra-industry in ASEAN to increase needs efficient engine of developing infra-structure to support the expansion of trade and investment such as the transportation link via ports, airports, railways, and roads. Furthermore, both the East-West and North-South Corridors have to be progressively built to create the commodity delivery route with the region and contribute to transportation costs reduction between ASEAN and China.

Besides, the production pattern of almost ASEAN members has been altered from the agriculture to manufacture during the past two decades. This can be affirmed by the massive inflow of foreign direct investment (FDI) especially in high competitiveness export manufacture industries before the attack of economic and financial crisis. Trade and investment facilitation schemes are also very crucial to assure the effective policy implementation.

\section{Trade and Investment Liberalisation Under AEC}

This section analyses the roles and importance of regional economic integration. Regional economic integration has been proliferated in many regions including Asia. It has an importance as first those countries in the same region develop the agreements to expand the economic cooperation not only for trade and investment 
liberalisation but also to enhance the effective alleviation economic and financial crises polices. The free trade agreements (FTAs) can be used as possible measure to deal with this issue.

The current important example of regional economic integration is ASEAN. ASEAN has an increasingly important role in terms of not only regional trade and investment liberalisation but also the expanding of other and deeper economic integration to be the ASEAN Economic Community (AEC) by the end of 2015 (Wattanakul, 2010). The ultimate goals of AEC are to be single market in order to create the efficient production hub and network. Furthermore, the service sector liberalisation is also the additional important target of AEC.

Bilateral free trade agreements (FTAs) are an essential step that can lead to the building blocks for the comprehensive regional economic cooperation and plurilateral economic integration later. Many countries in ASEAN currently, particularly Thailand, have enthusiastically negotiated and implemented the bilateral FTAs. Thailand has signed and implemented the bilateral FTAs with the countries both inside and outside the region.

In addition, the enlarged ASEAN has been progressed because the major East Asian countries of China, Japan, and South Korea are very interested to be part of AEC as the ASEAN + 3 (Wattanakul, 2010). This progress will be beneficial to all partners and lead to the more negotiation power under the WTO and other mutual benefits. Another enlarged ASEAN negotiation and progress in the present is ASEAN +6 . ASEAN +6 consists of 10 ASEAN members and China, Japan, South Korea, Australia, New Zealand, and India. All mentioned East Asia economies are very important for regional economy's growth because of the massive foreign direct investment (FDI) in export manufacturing in ASEAN host countries.

\section{Level of Intra-industry Trade on ASEAN's Economy}

This section describes level and impact of specific intra-industry trade on the selected ASEAN member's economy. The analysis of related macroeconomic and trade data are used to analyse by using descriptive statistics as well as tables and figures.

The data used to examine and analyse consist of total trade, trade aggregate, trade balance, total trade share to GDP, trade structure, and trade dependency. These data obtained from the ASEAN Community in Figures 2011 (ACIF, 2011).

Table 1

ASEAN Trade (US \$ Million)

\begin{tabular}{|c|c|c|c|c|c|c|}
\hline Indicator & 1998 & 2000 & 2003 & 2008 & 2009 & 2010 \\
\hline Total trade & 576,108 & 759,101 & 824,539 & $1,897,127$ & $1,536,878$ & $2,045,731$ \\
\hline Intra-ASEAN trade & 120,918 & 166,846 & 206,732 & 470,112 & 376,177 & 519,805 \\
\hline Extra-ASEAN trade & 455,190 & 592,255 & 617,807 & $1,427,015$ & $1,160,700$ & $1,525,926$ \\
\hline Trade balance & 57,194 & 61,180 & 80,575 & 57,946 & 84,068 & 96,152 \\
\hline
\end{tabular}

Source: ASEAN Trade Statistics Database, 2011.

From Table 1, it shows that ASEAN trade reached US $\$ 2.0$ trillion in 2010 with an increase by $33.1 \%$ due to expansion in trade with both intra- and extra-ASEAN partners. Intra-ASEAN's share to ASEAN total trade in 2010 stood at $25.4 \%$ that was slightly higher than $24.5 \%$ in 2009 . Meanwhile, extra-ASEAN, accounted for three-fourths of total ASEAN trade that grew by $31.5 \%$, in 2010 following recovery from the 2008 global economic downturn. In addition, the share of exports to GDP rose steadily in tandem with the ratio of imports 
to GDP. ASEAN continued to register trade surplus in 2010 amounting to US \$96 billion as demand for ASEAN export products remained strong.

Table 2

Total Trade (US \$ Million)

\begin{tabular}{lllllll}
\hline Country & 1998 & 2000 & 2003 & 2008 & 2009 & 2010 \\
\hline Brunei Darussalam & 3,200 & 3,237 & 4,563 & 12,775 & 9,602 & 10,999 \\
Cambodia & n.a. & 2,772 & 5,022 & 8,776 & 8,887 & 10,480 \\
Indonesia & 76,185 & 95,639 & 93,609 & 266,218 & 213,339 & 293,442 \\
Lao PDR & n.a. & n.a. & 482 & 2,631 & 2,962 & 4,509 \\
Malaysia & 138,075 & 177,802 & 188,502 & 338,795 & 280,221 & 363,534 \\
Myanmar & n.a. & 3,413 & 6,307 & 10,415 & 10,191 & 11,798 \\
Philippines & 59,156 & 72,569 & 73,728 & 105,671 & 83,869 & 109,660 \\
Singapore & 211,299 & 273,033 & 296,116 & 657,956 & 515,617 & 699,273 \\
Thailand & 88,193 & 130,636 & 156,210 & 352,534 & 286,267 & 385,041 \\
Vietnam & n.a. & n.a. & n.a. & 141,357 & 125,922 & 156,993 \\
\hline
\end{tabular}

Source: ASEAN Trade Statistics Database, 2011.

Table 3

Total Trade Share to the GDP (\%)

\begin{tabular}{lllllll}
\hline Country & 1998 & 2000 & 2003 & 2008 & 2009 & 2010 \\
\hline Brunei Darussalam & 79.8 & 54.0 & 69.8 & 88.4 & 89.3 & 88.7 \\
Cambodia & n.a. & 76.6 & 108.4 & 79.2 & 85.8 & 93.8 \\
Indonesia & 72.2 & 57.8 & 39.8 & 51.9 & 39.0 & 41.4 \\
Lao PDR & n.a. & n.a. & 22.6 & 49.8 & 53.1 & 69.3 \\
Malaysia & 191.1 & 196.9 & 181.3 & 152.1 & 145.1 & 152.2 \\
Myanmar & n.a. & 35.5 & 53.7 & 45.6 & 40.8 & 27.4 \\
Philippines & 90.2 & 97.0 & 92.6 & 63.5 & 52.0 & 57.9 \\
Singapore & 248.5 & 289.5 & 308.6 & 340.0 & 282.2 & 313.6 \\
Thailand & 78.2 & 106.2 & 109.3 & 129.2 & 108.3 & 120.8 \\
Vietnam & n.a. & n.a. & n.a. & 156.2 & 130.7 & 145.8
\end{tabular}

Source: ASEAN Trade Statistics Database, 2011.

From Tables 2 and 3, it can be stated that nearly all members had an increase in total trade led to the increase of share to GDP. This trend emerged particular for during the period between 1998 and 2000 attributed to the recovery period from the economic and financial crisis. Other important factor contributed to the trade and investment liberalisation under the AFTA. The fluctuation period was during the period between 2003 and 2010 because of the recession in some countries. However, during this period the trade balance of all new members of Cambodia, Lao PDR, Myanmar, and Vietnam (CLMV) was deficit including the Philippines.

From Tables 4 and 5, it can be affirmed that the top 20 export commodities represented less than $50 \%$ of total export value which means that the ASEAN has diversified its export products to meet not only the ASEAN regional but also new global demands. Besides, the top 20 import commodity items made up less than $40 \%$ of total import value. This supports the production and trade structure of the region from agricultural to manufactured products. This obviously altered change that can contribute to the effective trade and investment liberalisation policy implementation to boost the intra-industry trade expansion. 
Table 4

ASEAN Top 20 Export Commodities in 2010

\begin{tabular}{|c|c|c|c|}
\hline HS codes & Commodities & $\begin{array}{l}\text { Value share } \\
\text { (US \$ Million) }\end{array}$ & Share $(\%)$ \\
\hline 8542 & Electronic integrated circuits and micro-assemblies & 97,644 & 9.1 \\
\hline 2710 & Petroleum oils, not crude & 61,945 & 5.8 \\
\hline 8471 & Automatic data processing machines; optical reader, etc. & 40,779 & 3.8 \\
\hline 2711 & Petroleum gases & 34,107 & 3.2 \\
\hline 2709 & Crude petroleum oils & 28,699 & 2.7 \\
\hline 8473 & Parts/acc. of computers \& office machines & 26,646 & 2.5 \\
\hline 1511 & Palm oil \& its fraction & 26,057 & 2.4 \\
\hline 4001 & Natural rubber, in primary form or plates & 20,512 & 1.9 \\
\hline 2701 & Coal, briquettes, ovoids, and similar solid fuels manufactured from coal & 19,852 & 1.9 \\
\hline 8541 & Diodes/transistors \& similar semiconductor devices, etc. & 17,109 & 1.6 \\
\hline 8443 & Printing machinery; machines used for ancillary to printing & 12,926 & 1.2 \\
\hline 7108 & Gold, unwrought or in semi-manufactured forms & 11,468 & 1.1 \\
\hline 8708 & Parts \& access of motor vehicles & 10,140 & 0.9 \\
\hline 8517 & Electric appliance for line telephony (incl. current line system) & 9,854 & 0.9 \\
\hline 8528 & Television receivers (incl. video monitors and projectors) & 8,613 & 0.8 \\
\hline 8703 & $\begin{array}{l}\text { Motor cars and vehicles for transporting persons } \\
\text { (except public transport motor vehicles) }\end{array}$ & 8,606 & 0.8 \\
\hline 2603 & Copper ores and concentrates & 7,658 & 0.7 \\
\hline 1006 & Rice & 7,351 & 0.7 \\
\hline 8523 & Prepared, unrecorded media (no film) for sound etc. & 6,679 & 0.6 \\
\hline \multirow[t]{4}{*}{8536} & $\begin{array}{l}\text { Electrical appliances for electrical connection } \\
\text { (i.e. fuse, switch, etc.), not exceeding 1,000 volt }\end{array}$ & 6,593 & 0.6 \\
\hline & Top 20 export commodities & 463,240 & 43.3 \\
\hline & Others & 607,701 & 56.7 \\
\hline & Total & $1,070,941$ & 100.0 \\
\hline
\end{tabular}

Source: ASEAN Trade Statistics Database, 2011.

Table 5

ASEAN Top 20 Import Commodities in 2010

\begin{tabular}{|c|c|c|c|}
\hline HS codes & Commodities & $\begin{array}{l}\text { Value share } \\
\text { (US \$ Million) }\end{array}$ & Share $(\%)$ \\
\hline 8542 & Electronic integrated circuits and micro-assemblies & 92,766 & 9.5 \\
\hline 2710 & Petroleum oils, not crude & 82,656 & 8.5 \\
\hline 2709 & Crude petroleum oils & 31,731 & 3.3 \\
\hline 8471 & Automatic data processing machines; optical reader, etc. & 20,605 & 2.1 \\
\hline 8473 & Parts \& accessories of computers \& office machines & 20,548 & 2.1 \\
\hline 8517 & Electric appliance for line telephony (included current line system) & 17,747 & 1.8 \\
\hline 7108 & Gold, unwrought, or in semi-manufactured forms & 12,694 & 1.3 \\
\hline 8703 & $\begin{array}{l}\text { Motor cars \& vehicles for transporting persons } \\
\text { (except public transport motor vehicles) }\end{array}$ & 12,202 & 1.3 \\
\hline 8708 & Parts \& accessories of motor vehicles & 11,058 & 1.1 \\
\hline 8541 & Diodes/transistors \& semiconductor devices, etc. & 10,188 & 1.0 \\
\hline 8443 & Printing machinery, machines for uses ancillary to printing & 8,043 & 0.8 \\
\hline 8529 & Part suitable for use solely/principally with televisions & 7,664 & 0.8 \\
\hline 8704 & Motor vehicles for transport of goods & 7,601 & 0.8 \\
\hline 4001 & Natural rubber in primary form or plates & 7,403 & 0.8 \\
\hline 8802 & Aircraft, powered, spacecraft \& launch vehicles helicopters, satellites & 7,105 & 0.7 \\
\hline
\end{tabular}


Table 5 continued

\begin{tabular}{|c|c|c|c|}
\hline HS codes & Commodities & $\begin{array}{l}\text { Value share } \\
\text { (US \$ Million) }\end{array}$ & Share $(\%)$ \\
\hline 8431 & $\begin{array}{l}\text { Parts of machinery (for lifting, handling, loading, unloading, scraping, boring, } \\
\text { extracting, and leveling) }\end{array}$ & 6,929 & 0.7 \\
\hline 8536 & $\begin{array}{l}\text { Electrical appliance for electrical connection } \\
\text { (i.e. fuse, switch, etc.), not exceeding } 1,000 \text { volt }\end{array}$ & 6,858 & 0.7 \\
\hline 1006 & Rice & 6,344 & 0.7 \\
\hline 8411 & Turbo-jets, turbo-propellers, and other gas turbines & 6,198 & 0.6 \\
\hline \multirow[t]{4}{*}{8479} & $\begin{array}{l}\text { Machines and mechanical appliances having individual functions, not specified } \\
\text { or included elsewhere }\end{array}$ & 5,477 & 0.6 \\
\hline & Top 20 import commodities & 381,817 & 39.2 \\
\hline & Others & 592,973 & 60.8 \\
\hline & Total & 974,790 & 100.0 \\
\hline
\end{tabular}

Source: ASEAN Trade Statistics Database, 2011.

\section{Discussion}

The essential contribution to knowledge of this study attributes to primary empirical results by using appropriate econometric model and estimation techniques to confirm whether the increasing of specific intra-industry trade in ASEAN region leads to economy growth of selected member. These important results can be used as the mutual agreement consideration of trade and investment liberalisation policy implementations and recommendations in the previous section.

\section{Summary}

From the above, it can be summerised that many countries in Asia have been affected by the economic crisis during the past two decades although these countries have experienced continued economic growth. Nearly all countries especially in the ASEAN region have also affected considerably. This situation and challenge caused the global economy imbalances. Therefore, these affected countries need to implement effective economic policies to response and solve the challenges.

Furthermore, the regional economic integration is a possible channel that can be applied to use as the solution. Consequently, the bilateral FTAs have developed both inside and outside the region. The enlarged ASEAN in terms of ASEAN +3 and ASEAN +6 is the opportunity to expand the economic collaboration to alleviate the adverse impacts and prevent the re-emerge of the crisis including the other economic collaboration. The currently obvious example of this proposes is AEC that the ultimate goal as single market is targeted by the end of 2015. The plausible mutual benefits from the single AEC market need to be deeply examined to support this argument.

\section{Suggestions for Further Studies}

This study can be extended in terms of both the development of appropriate econometric model to estimate by using suitable methods to strongly confirm via reliable and plausible empirical results of intra-industry trade. The other specific intra-industry trade in ASEAN as well as in Greater Mekong Sub-region (GMS) can also be selected to compare the results.

\section{References}

Appleyard, D. R., \& Field, A. J. (1997). International economics (3rd ed.). New York: Irwin McGraw-Hill. 
ASEAN Community in Figures (ACIF). (2011). ASEAN Secretariat, 2012. Jakarta.

Dowling, M. J., \& Valenzuela, R. M. (2004). Economic development in Asia. Thomson Learning (a division of Thomson Asia Pte Ltd.), Singapore.

Elliott, R. J., \& Ikemoto, K. (2004). AFTA and the Asian crisis: Help or hindrance to ASEAN intra-regional trade? ASEAN Economic Journal, 18(1), 1-23.

Wattanakul, T. (2010). Thailand's openness and implications for economic and trade policy: An econometric study (submitted in fulfillment of the requirement for the degree of doctor of philosophy). Centre for Strategic Economic Studies, Faculty of Business and Law, Victoria University, Melbourne, Australia, November 2010. 